\title{
KUALITAS PELAYANAN RAWAT JALAN PUSKESMAS TANJUNG PALAS BERDASARKAN METODE IMPORTANCE PERFORMANCE ANALYSIS
}

\author{
Imam Muazansyah \\ Fakultas Ilmu Sosial dan Ilmu Politik Universitas Kaltara, alyacarpet@ gmail.com, \\ Irsyad Sudirman \\ Fakultas Ilmu Sosial dan Ilmu Politik Universitas Kaltara, isman.dodi77@gmail.com
}

\begin{abstract}
ABSTRAK
Penelitian ini untuk menganalisis kualitas pelayanan rawat jalan Puskesmas Tanjung Palas dengan metode Importance Performance Analysis. Pengambilan populasi menggunakan non probability sampling melalui convenience sampling. Kuesioner disebarkan kepada 99 responden yang merupakan sampel pasien rawat jalan di puskesmas Tanjung Palas. Indeks kepuasan pasien rawat jalan dengan menggunakan Importance Performance Analysis (IPA) memperoleh hasil penelitian bahwa kualitas layanan sangat berdampak pada kepuasan pasien pengguna layanan jasa tersebut dengan dibuktikan kenyataan atau kinerja Puskesmas yang jauh dari harapan pasien, pasien kurang puas akan pelayanan yang diberikan oleh Puskesmas khususnya pada atribut atau kuadran I yaitu kebersihan Puskesmas, kelengkapan alat medis, dan kehandalan tenaga kesehatan baik dokter maupun perawat.
\end{abstract}

Kata kunci: $\quad$ Kualitas Pelayanan, Kepuasan Pasien, Importance and Performance Analysis

Abstract

This study was to analyze the quality of outpatient services at Tanjung Palas Community Health Center using the Importance Performance Analysis method. Population collection uses non probability sampling through convenience sampling. The questionnaire was distributed to 99 respondents who were samples of outpatients at the Tanjung Palas health center. The outpatient satisfaction index using the Importance Performance Analysis (IPA) obtained the results of research that service quality had a significant impact on patient satisfaction with service users with proven reality or performance of health centers that were far from patient expectations, patients were less satisfied with the services provided by the Center health, especially in attributes or quadrant I, namely cleanliness of the health center, completeness of medical devices, and reliability of health personnel both doctors and nurses.

Keyword : Service Quality, Patient Satisfaction, Importance and Performance Analysis 


\section{PENDAHULUAN}

Nawa Cita adalah program yang dicanangkan pada saat kepemimpinan Jokowi dan Jusuf Kalla. Program Indonesia Sehat merupakan program Nawacita yang kelima dan menjadi program utama Pembangunan Kesehatan yang ditetapkan berdasarkan Keputusan Menteri Kesehatan R.I. Nomor HK.02.02/Menkes/52/2015 dengan tujuan meningkatkan kualitas hidup manusia bidang kesehatan di Indonesia. Pelayanan kesehatan merupakan hak dasar setiap individu dan semua Warga Negara maka program ini didukung oleh Program Indonesia Pintar, Program Indonesia Kerja, dan Program Indonesia Sejahtera.

Berdasarkan Peraturan Menteri Kesehatan Republik Indonesia Nomor 75 Tahun 2014 dan Peraturan Daerah Provinsi Kaltara Nomor 2 Tahun 2017, Puskesmas sebagai salah satu ujung tombak pelayanan kesehatan dasar (strata I) dengan menyelenggarakan program pokok bidang kesehatan (public health essential) sebagai upaya promotif dan preventif kesehatan perorangan (private goods) maupun kesehatan masyarakat (public goods).

Penurunan jumlah kunjungan pasien rawat jalan di Puskesmas Tanjung Palas tahun 2016 adalah

15.402 orang (Sumber: Bidang Yankes dan SDK Dinkes di Kabupaten Bulungan tahun 2017), jumlah kunjungan pasien tahun 2017 mengalami penurunan hingga mencapai 10.122 orang. (sumber: Subbag Perencanaan \& Keuangan Dinkes, 2018). Penurunan jumlah kunjungan masyarakat ke puskesmas karena masyarakat tidak puas pada pelayanan puskesmas. Rasa tidak puas yang dirasakan pasien menunjukkan bahwa kondisi pelayanan kesehatan yang diberikan oleh puskesmas Tanjung Palas belum mampu memenuhi harapan dan belum maksimal kepada warga Tanjung Palas dan sekitarnya mulai dari sarana

prasarana kesehatan, kualitas tenaga kesehatan (sumber daya manusia), pembiayaan kesehatan hingga kesejahteraan tenaga kesehatan..

\section{KAJIAN PUSTAKA}

\section{Pelayanan}

Berdasarkan Undang-Undang Nomor 25 Tahun 2009 dan Peraturan Pemerintah Nomor 96 Tahun 2012 menerangkan Pelayanan Publik merupakan serangkaian kegiatan pemenuhan kebutuhan pelayanan bagi masyarakat dan penduduk atas barang, jasa, dan/atau pelayanan administratif yang disediakan oleh penyelenggara pelayanan publik. Setiap institusi penyelenggara negara, korporasi, lembaga independen yang dibentuk untuk menyelenggarakan kegiatan pelayanan publik. Pemberi pelayanan publik meliputi pejabat, pegawai dan petugas organisasi pelayanan yang bertugas melaksanakan tindakan atau serangkaian tindakan pelayanan publik. Individu, kelompok, maupun berbadan hukum baik secara langsung maupun tidak langsung berkedudukan sebagai penerima manfaat pelayanan publik disebut masyarakat.

Kualitas layanan menurut Wyckof dalam Algifari (2016), bahwa tingkat keunggulan yang diharapkan dan pengendalian atas tingkat keunggulan tersebut untuk memenuhi keinginan masyarakat. Zeithaml dkk (1990) dalam Muazansyah (2018) bahwa pelayanan diharapkan konsumen (expected service) dan pelayanan diterima oleh pengguna (perceived service) merupakan dua faktor yang memengaruhi kualitas layanan. Baik tidaknya kualitas layanan tergantung pada penilaian kemampuan pemberi atau penyelenggara pelayanan dalam memenuhi harapan secara konsisten. Pelayanan yang diterima atau yang dirasakan (perceived service) sesuai dengan pelayanan yang diharapkan, maka kualitas layanan dipersepsikan baik dan memuaskan. Pelayanan yang diterima melampaui harapan konsumen, maka kualitas layanan yang dipersepsikan sebagai kualitas yang ideal. Sebaliknya jika pelayanan yang diterima lebih rendah dari pada pelayanan yang diharapkan, maka kualitas layanan dipersepsikan buruk.

Metode servqual (service quality) digunakan dan diterapkan baik organisasi yang berorientasi laba maupun berorientasi nirlaba.

Pengukuran kualitas pelayanan menurut Zeithaml et.al. (1990) memiliki sepuluh dimensi, yaitu: 1) Tangibles (berwujud fisik); 2) Reliability (kehandalan); 3) Responsiveness (ketanggapan);

4) Competence (kompeten); 5) Courtesy (ramah);

6) Credibility (dapat dipercaya); 7) Security (merasa aman); 8)

Access (akses); 9) Communication (komunikasi);

10) Understanding the customer (memahami pelanggan), serta melakukan segala usaha untuk mengetahui kebutuhan pelanggan.

Berdasarkan sepuluh dimensi kualitas pelayanan tersebut, kemudian Zeithaml et.al. (1990) 
menyederhanakan menjadi lima dimensi, yaitu: (1)

Tangibles. Appearance of physical

facilities, equipment, personnel, and communication materials; (2) Reliability. Ability to perform the promised service dependably and accurately; (3) Responsiveness. Willingness to help customers and provide prompt service; (4) Assurance. Knowledge and courtesy of employees and their ability to convey trust and confidence; and (5) Empathy. The firm provides care and individualized attention to its customers.

Indeks Kepuasan Masyarakat Pelanggan dengan 14 (empat belas) unsur minimal berdasarkan Permenpan No. 14 Tahun 2017 untuk mengukur kinerja pelayanan, yakni:

1. Prosedur 2. Persyaratan 3. Kejelasan petugas

4. Disiplin petugas 5. Tanggungjawab petugas

6. Kemampuan petugas 7. Kecepatan pelayanan

8. Keadilan pelayanan 9. Sopan dan Ramah petugas 10 . Kewajaran biaya Pelayanan 11. Kepastian biaya pelayanan 12. Kepastian Jadwal Pelayanan 13 Kenyamanan Lingkungan

14. Keamanan Pelayanan

Keluaran "outcome" layanan kesehatan adalah kepuasan pasien dimana

kepuasan pasien dapat menunjukkan peningkatan mutu layanan kesehatan. Tingkat perasaan pasien yang timbul sebagai akibat dari kinerja layanan kesehatan yang diperoleh pasien setelah pasien membandingkan dengan apa yang diharapkannya (Pohan, 2013 dalam Riadi, 2016).

\section{METODE PENELITIAN}

Metode penelitian kuantitatif deskriptif

berdasarkan metode IPA (Importance

Performance dan Analysis). Penelitian dilaksanakan di Puskesmas Tanjung Palas, Kabupaten Bulungan Provinsi Kalimantan Utara (Jl. Padat Karya Gunung Putih, Bulungan) pada bulan Juli hingga Desember 2018.

Pengambilan sampel dilakukan dengan non probability sampling melalui convenience sampling. Responden yang dijadikan sampel adalah pasien yang sebelumnya pernah berkunjung di puskesmas Tanjung Palas. Besarnya sampel penelitian ini sebanyak 99 responden.

Teknik analisis data berdasarkan Importance Performance Analysis (IPA) dengan menampilkan diagram kartisius dengan membandingkan antara kepuasaan pasien umum rawat jalan di Puskesmas Tanjung Palas dengan kinerja pelayanan rawat inap Puskesmas Tanjung Palas melalui pengukuran lima variabel meliputi tangible (bukti fisik), reliability (kehandalan), responsiveness (daya tanggap), assurance (jaminan), dan empathy (empati).

\section{ANALISIS DAN PEMBAHASAN}

Berdasarkan hasil temuan bahwa analisis deskriptif menggambarkan jawaban responden prioritas peningkatan kualitas pelayanan dengan yang dirasakan oleh pasien quadrant analysis pada nilai rata rata, standar deviasi, dan ImportancePerformance Analysis (IPA) untuk mengukur hubungan antara kepuasan pasien dengan prioritas peningkatan kinerja pelayanan Puskesmas Tanjung Palas.

Tabel 1. Deskriptif Rata-rata Jawaban Responden Kualitas Layanan pada Pasien di Puskesmas Tanjung Palas.

\begin{tabular}{|c|c|c|c|}
\hline \multirow[b]{2}{*}{ Item } & \multirow[b]{2}{*}{ Pernyataan } & \multicolumn{2}{|c|}{ Rata-rata } \\
\hline & & $\begin{array}{c}\text { Kepentingan } \\
\text { (Harapan) }\end{array}$ & $\begin{array}{c}\text { Kinerja } \\
\text { (Kenyataan) }\end{array}$ \\
\hline \multicolumn{4}{|c|}{ Tangible (Bukti Fisik) } \\
\hline \multirow[b]{2}{*}{$\mathrm{T} 1$} & \multirow{2}{*}{$\begin{array}{l}\text { Puskesmas Tanjung } \\
\text { Palas Kabupaten } \\
\text { Bulungan, } \\
\text { Kalimantan Utara } \\
\text { bersih }\end{array}$} & \multirow[b]{2}{*}{4.79} & 2.63 \\
\hline & & & Tidak puas \\
\hline \multirow[b]{2}{*}{$\mathrm{T} 2$} & \multirow{2}{*}{$\begin{array}{l}\text { Puskesmas Tanjung } \\
\text { Palas Kabupaten } \\
\text { Bulungan, } \\
\text { Kalimantan Utara }\end{array}$} & \multirow[b]{2}{*}{4.64} & 2.53 \\
\hline & & & Tidak puas \\
\hline
\end{tabular}




\begin{tabular}{|c|c|c|c|}
\hline \multirow{3}{*}{ Item } & \multirow{3}{*}{$\begin{array}{l}\quad \text { Pernyataan } \\
\text { memiliki alat medis } \\
\text { lengkap }\end{array}$} & \multicolumn{2}{|c|}{ Rata-rata } \\
\hline & & $\begin{array}{c}\text { Kepentingan } \\
\text { (Harapan) }\end{array}$ & $\begin{array}{c}\text { Kinerja } \\
\text { (Kenyataan) }\end{array}$ \\
\hline & & & \\
\hline \multirow[b]{2}{*}{$\mathrm{T} 3$} & $\begin{array}{|ll|}\text { Tenaga } & \text { kesehatan } \\
\end{array}$ & \multirow[b]{2}{*}{4.47} & 2.94 \\
\hline & \begin{tabular}{|l} 
Puskesmas Tanjung \\
Palas Kabupaten \\
Bulungan, \\
Kalimantan Utara \\
berpenampilan \\
bersih
\end{tabular} & & Tidak puas \\
\hline \multicolumn{4}{|c|}{ Reliability (Kehandalan) } \\
\hline \multirow[b]{2}{*}{$\mathrm{R} 1$} & \multirow{2}{*}{$\begin{array}{l}\text { Tenaga kesehatan } \\
\text { kompeten dalam } \\
\text { memberikan } \\
\text { pelayanan }\end{array}$} & \multirow[b]{2}{*}{4.82} & 3.58 \\
\hline & & & Tidak puas \\
\hline \multirow[b]{2}{*}{ R2 } & \multirow{2}{*}{$\begin{array}{l}\text { Tenaga kesehatan } \\
\text { bertindak cepat } \\
\text { dalam menangani } \\
\text { pasien }\end{array}$} & \multirow[b]{2}{*}{4.76} & 3.35 \\
\hline & & & Tidak puas \\
\hline \multirow[b]{2}{*}{ R3 } & \multirow{2}{*}{\begin{tabular}{|l|} 
Prosedur \\
penerimaan pasien \\
tidak berbelit-belit
\end{tabular}} & \multirow[b]{2}{*}{4.66} & 3.15 \\
\hline & & & Tidak puas \\
\hline \multicolumn{4}{|c|}{ Responsiveness (Daya Tanggap) } \\
\hline \multirow{2}{*}{ RES1 } & \multirow{2}{*}{\begin{tabular}{|l|} 
Tenaga kesehatan \\
Puskesmas siap \\
selama 24 jam
\end{tabular}} & 4.59 & 3.01 \\
\hline & & & Tidak puas \\
\hline \multirow[b]{2}{*}{ RES2 } & \multirow[b]{2}{*}{ 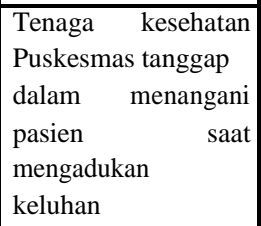 } & \multirow[b]{2}{*}{4.68} & 3.00 \\
\hline & & & Tidak puas \\
\hline \multirow[b]{2}{*}{ RES3 } & \multirow[b]{2}{*}{\begin{tabular}{|lr|}
\multicolumn{3}{|l|}{ Kecepatan } & \\
pelayanan pada saat \\
menangani & pasien \\
meskipun & kondisi \\
ramai & \\
\end{tabular}} & \multirow[b]{2}{*}{4.60} & 3.02 \\
\hline & & & Tidak puas \\
\hline \multicolumn{4}{|c|}{ Assurance (Jaminan) } \\
\hline \multirow[b]{2}{*}{ A1 } & \multirow[b]{2}{*}{\begin{tabular}{|lr}
\multicolumn{2}{|l}{ Puskesmas Tanjung } \\
Palas r & Kabupaten \\
Bulungan, & \\
Kalimantan & Utara \\
memiliki & tenaga \\
yang & handal baik \\
dokter & maupun \\
perawat & \\
\end{tabular}} & \multirow[b]{2}{*}{4.57} & 2.70 \\
\hline & & & Tidak puas \\
\hline \multirow[b]{2}{*}{ A2 } & \multirow[b]{2}{*}{$\begin{array}{|lr|}\text { Jaminan } & \text { ketepatan } \\
\text { waktu r r } & \text { yang } \\
\text { diberikan } & \\
\text { Puskesmas } & \text { Tanjung } \\
\text { Palas r } & \text { Kabupaten } \\
\text { Bulungan, } & \\
\text { Kalimantan r Utara } \\
\text { dalam r memberikan } \\
\text { pelayanan }\end{array}$} & \multirow[b]{2}{*}{4.42} & 3.20 \\
\hline & & & Tidak puas \\
\hline \multirow[b]{2}{*}{ A3 } & \multirow{2}{*}{$\begin{array}{l}\text { Puskesmas Tanjung } \\
\text { Palas Kabupaten } \\
\text { Bulungan, } \\
\text { Kalimantan Utara } \\
\text { memberikan }\end{array}$} & & 3.55 \\
\hline & & 4.11 & Tidak puas \\
\hline
\end{tabular}




\begin{tabular}{|c|c|c|c|}
\hline \multirow{3}{*}{ Item } & \multirow{3}{*}{$\begin{array}{l}\text { Pernyataan } \\
\text { jaminan } \\
\text { kenyamanan bagi } \\
\text { pasien yang berobat }\end{array}$} & \multicolumn{2}{|c|}{ Rata-rata } \\
\hline & & $\begin{array}{c}\text { Kepentingan } \\
\text { (Harapan) }\end{array}$ & $\begin{array}{c}\text { Kinerja } \\
\text { (Kenyataan) }\end{array}$ \\
\hline & & & \\
\hline \multicolumn{4}{|c|}{ Empathy (empati) } \\
\hline \multirow[b]{2}{*}{ E1 } & \multirow{2}{*}{$\begin{array}{l}\text { Tenaga kesehatan } \\
\text { Puskesmas ramah } \\
\text { dalam melayani } \\
\text { pasien }\end{array}$} & \multirow[b]{2}{*}{4.12} & 2.85 \\
\hline & & & Tidak puas \\
\hline \multirow[b]{2}{*}{ E2 } & \multirow[b]{2}{*}{\begin{tabular}{l} 
Tenaga kesehatan \\
Puskesmas \\
berusaha \\
menenangkan rasa \\
cemas pasien \\
terhadap penyakit \\
\multicolumn{2}{l}{ yang diderita }
\end{tabular}} & \multirow[b]{2}{*}{4.51} & 2.69 \\
\hline & & & Tidak puas \\
\hline \multirow[b]{2}{*}{ E3 } & \multirow[b]{2}{*}{$\begin{array}{l}\text { Tenaga kesehatan } \\
\text { Puskesmas } \\
\text { memberikan } \\
\text { perhatian dengan } \\
\text { memperlakukan } \\
\text { pasien secara } \\
\text { personal }\end{array}$} & \multirow[b]{2}{*}{4.12} & 2.74 \\
\hline & & & Tidak puas \\
\hline \multicolumn{2}{|c|}{$\begin{array}{c}\text { Nilai Mean Kepentingan } \\
\text { (Harapan) dan Kinerja } \\
\text { (Kenyataan) Kualitas } \\
\text { Layanan }\end{array}$} & 4.52 & 2.99 \\
\hline
\end{tabular}

Berdasarkan Tabel 2, diketahui bahwa responden menginginkan harapan sangat tinggi atas pelayanan yang diberikan Puskesmas Tanjung Palas, hal ini dibuktikan dari rata-rata jawaban responden untuk masing-masing pernyataan dari kualitas pelayanan dengan nilai rata-rata sebesar 4.52 yang berarti Sangat Penting. Kinerja Puskesmas Tanjung Palas menyatakan bahwa responden masih dalam kategori cukup atau dinyatakan kurang dengan nilai rata-rata sebesar 2.99 yang berarti Cukup Penting.

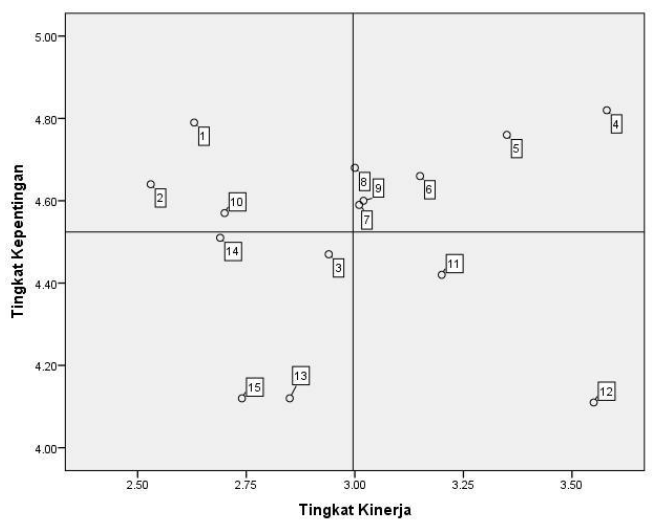

Gambar 1. Diagram Kartesius antara Harapan dan Kenyataan Layanan Puskesmas Tanjung Palas.

Gambar 1. menggambarkan posisi untuk atribut kualitas pelayanan dari pihak Puskesmas Tanjung Palas antara tingkat kepentingan atau harapan pasien dengan yang kenyataan atau kinerja Puskesmas Tanjung Palas dalam memberikan pelayanan. Acuan mean keseluruhan kepentingan (harapan) pasien dari variabel kualitas pelayanan (4.52) dan mean keseluruhan kinerja (kenyataan) Puskesmas Tanjung Palas dari variabel kualitas pelayanan $(2,99)$ sebagai sumbu koordinat. Dari gambar diagram kartesius (Gambar 4.2) dianalisis sebagai berikut:

\section{Kuadran I}

Atribut yang terletak di kuadran I menyatakan atribut tersebut memiliki tingkat harapan lebih tinggi daripada mean variabel harapan dan tingkat kenyataan lebih rendah daripada mean variabel kenyataan secara keseluruhan.

Atribut kuadran I, yaitu:

1. Kebersihan Puskesmas Tanjung Palas (T1) menunjukkan Kepentingan (Harapan) memiliki rata-rata sebesar 4.79 dengan Kinerja (Kenyataan) memperoleh nilai rata-rata lebih rendah sebesar 2.63 bahwa responden merasa tidak puas terhadap kebersihan Puskesmas Tanjung Palas.

2. Puskesmas Tanjung Palas memiliki alatmedislengkap(T2) menunjukkan Kepentingan (Harapan) memiliki rata-rata sebesar 4.64 dengan Kinerja (Kenyataan) memperoleh nilai rata-rata lebih rendah sebesar 2.53 bahwa responden

merasa tidak puas terhadap kelengkapan alat medis yang disediakan oleh Puskesmas Tanjung Palas.

3. Puskesmas Tanjung Palas memiliki tenaga yang handal baik dokter maupun perawat (A1) menunjukkan Kepentingan (Harapan) memiliki ratarata sebesar 4.57 dengan Kinerja 
(Kenyataan) memperoleh nilai ratarata lebih rendah sebesar 2.70 bahwa responden merasa tidak puas

terhadap kehandalan tenaga kesehatan baik dokter maupun perawat yang ada di Puskesmas Tanjung Palas.

Untuk pihak pengelola Puskesmas Tanjung Palas hendaknya memperhatikan ketiga atribut di atas, sehingga merupakan prioritas utama yang harus diperhatikan. Prosedur pelayanan yang diberikan kepada pasien di Puskesmas Tanjung Palas harus dapat memenuhi harapan pasien atas atribut-atribut tersebut. Jika pihak Puskesmas Tanjung Palas tidak memenuhi, maka pasien tentunya akan memilih alternatif lainya yang lebih nyaman dan aman (tingkat kenyataan kinerja Puskesmas Tanjung Palas dibawah rata-rata).

\section{Kuadran II}

Atribut kuadran II menyatakan atribut tersebut memiliki tingkat harapan di atas mean variabel kualitas pelayanan harapan secara keseluruhan dan tingkat kenyataannya lebih tinggi daripada mean variabel kualitas pelayanan kenyataan secara keseluruhan. Atribut kuadran II, yaitu:

1. Tenaga kesehatan kompeten dalam memberikanpelayanan(R1) menunjukkan Kepentingan (Harapan) memiliki rata-rata sebesar 4.82 dengan Kinerja (Kenyataan) memperoleh nilai rata-rata lebih rendah sebesar 3.58 bahwa responden merasa tidak puas terhadap tenaga kesehatan yang kurang kompeten dalam memberikan pelayanan.

2. Tenaga kesehatan bertindak cepat dalam menangani pasien (R2) menunjukkan Kepentingan (Harapan) memiliki rata-rata sebesar 4.76 dengan Kinerja (Kenyataan) memperoleh nilai rata-rata lebih rendah sebesar 3.35 bahwa responden merasa tidak puas terhadap kecepatan tenaga kesehatan dalam menangani pasien.

3. Prosedur penerimaan pasien tidak berbelit-belit (R3) menunjukkan
Kepentingan (Harapan) memiliki rata-rata sebesar 4.66 dengan Kinerja (Kenyataan) memperoleh nilai rata-rata lebih rendah sebesar 3.15 bahwa responden merasa tidak puas terhadap prosedur penerimaan pasien yang berbelit-belit.

4. Tenaga kesehatan Puskesmas siap selama 24 jam (RES1) menunjukkan Kepentingan (Harapan) memiliki ratarata sebesar 4.59 dengan Kinerja (Kenyataan) memperoleh nilai ratarata lebih rendah sebesar 3.01 bahwa responden merasa tidak puas terhadap kesigapan tenaga kesehatan puskesman selama 24 jam.

5. Tenaga kesehatan Puskesmas tanggap menangani pasien saat mengadukankeluhan(RES2) menunjukkan Kepentingan (Harapan) memiliki rata-rata sebesar 4.68 dengan Kinerja (Kenyataan) memperoleh nilai rata-rata lebih rendah sebesar 3.00 bahwa responden merasatidakpuasterhadap ketanggapan tenaga kesehatan Puskesmas menangani pasien saat mengadukan keluhan.

6. Kecepatan pelayanan pada saat menangani pasien meskipun kondisi ramai (RES3) menunjukkan Kepentingan (Harapan) memiliki rata-rata sebesar 4.60 dengan Kinerja (Kenyataan) memperoleh nilai rata-rata lebih rendah sebesar 3.02 bahwa responden merasa tidak puas terhadap kecepatan pelayanan pada saat menangani pasien khususnya ketika kondisi ramai.

Walaupun tingkat kenyataan sudah lebih tinggi dari mean atribut kenyataan keseluruhan dari variabel kualitas pelayanan dan tingkat harapan berada di atas mean atribut harapan keseluruhan dari variabel kualitas pelayanan, atribut-atribut yang berada di kuadran II ini tidak boleh diabaikan oleh pihak Puskesmas Tanjung Palas. Justru pihak pengelola harus memberikan pelayanan yang berkaitan dengan atribut di atas sehingga pasien merasakan lebih 
puas dalam menggunakan Puskesmas Tanjung Palas sebagai jasa kebutuhan kesehatan.

\section{$\underline{\text { Kuadran III }}$}

Atribut kuadran III menyatakan atribut tersebut memiliki tingkat harapan di bawah mean atribut harapan variabel kualitas pelayanan secara keseluruhan dan memiliki tingkat kenyataan di bawah mean atribut kenyataan variabel kualitas pelayanan secara keseluruhan, walaupun begitu variabel pada kuadran III ini juga perlu mendapat perhatian karena tingkat kenyataannya rendah. Atribut kuadran III, yaitu:

1. Tenaga kesehatan berpenampilan bersih (T3) menunjukkan Kepentingan (Harapan) memiliki rata-rata sebesar 4.47 dengan Kinerja (Kenyataan) memperoleh nilai rata-rata lebih rendah sebesar 2.94 bahwa responden merasa tidak puas terhadap kebersihan penampilan tenaga kesehatan.

2. Tenaga kesehatan bersikap sopan, santun, ramah (E1) menunjukkan Kepentingan (Harapan) memiliki ratarata sebesar 4.12 dengan Kinerja (Kenyataan) memperoleh nilai rata-rata lebih rendah sebesar 2.85 bahwa responden responden merasa tidak puas terhadap keramahan tenaga kesehatan Puskesmas dalam melayani pasien.

3. Tenaga kesehatan Puskesmas berusaha menenangkan rasa cemas pasien terhadap penyakit yang diderita (E2) menunjukkan Kepentingan (Harapan) memiliki rata-rata sebesar 4.51 dengan Kinerja (Kenyataan) memperoleh nilai rata-rata lebih rendah sebesar 2.69 bahwa responden responden merasa tidak puas terhadap tenaga kesehatan yang kurang memberikan perhatian kepada pasien dalam menenangkan rasa cemas pasien akan penyakit yang diderita.

4. TenagakesehatanPuskesmas memberikan perhatian dengan memperlakukan pasien secara personal (E3) menunjukkan Kepentingan (Harapan) memiliki rata-rata sebesar 4.12 dengan Kinerja (Kenyataan) memperoleh nilai rata-rata lebih rendah sebesar 2.74 bahwa responden merasa tidak puas terhadap perhatian yang diberikan tenaga kesehatan Puskesmas dalam memperlakukan pasien secara personal.

Tingkat kenyataan yang lebih rendah daripada mean harapan secara keseluruhan merupakan kelemahan bagi Puskesmas Tanjung Palas. Oleh karena itu, pihak Puskesmas

Tanjung Palas harus benar-benar memperhatikan dan memberikan atau menyediakan fasilitas yang berhubungan dengan atribut di atas, sehingga dapat meningkatkan kepuasan pasien terhadap Puskesmas Tanjung Palas.

\section{Kuadran IV}

Atribut kuadran IV menyatakan atribut tersebut mempunyai tingkat harapan di bawah mean variabel kualitas pelayanan harapan secara keseluruhan dan tingkat kenyataannya di atas mean variabel kualitas pelayanan kenyataan secara keseluruhan.

Atribut kuadran IV, yaitu:

1. Pelayanan Jaminan ketepatan waktu (A2) menunjukkan Kepentingan (Harapan) memiliki rata-rata sebesar 4.42 dengan Kinerja (Kenyataan) memperoleh nilai rata-rata lebih rendah sebesar 3.20 bahwa responden merasa tidak puas dalam pelayanan jaminan ketepatan waktu yang diberikan Puskesmas Tanjung Palas.

2. Pelayanan jaminan kenyamanan bagi pasien yang berobat (A3). menunjukkan Kepentingan (Harapan) memiliki ratarata sebesar 4.11 dengan Kinerja (Kenyataan) memperoleh nilai rata-rata lebih rendah sebesar 3.55 bahwa responden merasa tidak puas terhadap jaminan kenyamanan yang diberikan

Puskesmas Tanjung Palas kepada pasien yang berobat.

Walaupun memperoleh tingkat harapan di bawah mean atribut harapan variabel kualitas pelayanan keseluruhan dan tingkat kenyataan di atas mean atribut kenyataan variabel kualitas pelayanan secara keseluruhan, namun pihak Puskesmas Tanjung Palas hendaknya tetap memperhatikan variabel-variabel tersebut sehingga diharapkan tingkat 
kepuasan pasien terhadap Puskesmas Tanjung Palas semakin meningkat.

\section{KESIMPULAN}

Berdasarkan uraian dan hasil kuadran dapat ditarik simpulan bahwa terdapat dampak pada kualitas layanan yang diberikan oleh Puskesmas Tanjung Palas pada kepuasan pasien. Hal ini terlihat dari adanya kualitas layanan yang kurang memenuhi harapan pasien yang mana harapan tinggi tidak sebanding dengan kinerja yang diberikan Puskesmas

Tanjung Palas Kabupaten Bulungan, Kalimantan Utara sehingga membuat pasien tidak puas terhadap kualitas pelayanan yang diberikan.

\section{SARAN}

Berdasarkan kesimpulan dan hasil temuan penelitian, maka saran yang diberikan yakni:

1. Bagi Puskesmas Tanjung Palas dapat meningkatkan kualitas pelayanan yang diberikan khususnya pada atribut I, yakni meningkatkan kebersihan Puskesmas, meningkatkan kelengkapan alat medis dan penampilan bersih tenaga kesehatannya.

2. Peneliti selanjutnya diharapkan Peneliti selanjutnya diharapkan tidak hanya meneliti satu Puskemas tetapi melakukan perbandingan antara satu puskesmas dengan puskemas lainnya dalam hal kualitaspelayanandanmelihat konsistensipenelitianmengenai Importance Performance Analysis Puskemas di daerah lainnya sehingga mendapatkan data yang lebih lengkap mengenai kualitas pelayanan. 


\section{DAFTAR PUSTAKA}

Algifari. (2016). Mengukur Kualitas Layanan dengan Indeks Kepuasan, Metode

Importance-Performance Analysis (IPA), dan Model Kano. Yogyakarta: BPFE

Eva Chisillia, Imam Muazansyah. 2018. Analisis Kualitas Pelayanan Terhadap Kepuasan Pasien Rawat Jalan Puskesmas (Pusat Kesehatan Masyarakat) Tanjung Palas Kabupaten Bulungan, Kalimantan Utara. Volume 4, Nomor 2. Jurnal Penelitian Administrasi Publik. Universitas 17 Agustus $1945 \quad$ Surabaya. http://jurnal.untag-

sby.ac.id/index.php/jpap/article/view/2300. Diakses pada tanggal 25 Maret 2019, Pukul 13.07 Wita.

Muhammad Iqbal. 2016. Analisis Kualitas Pelayanan Jasa Kesehatan (Studi Kasus:Puskesmas Batoh, Banda Aceh). http://etd.unsyiah.ac.id/index.php?p=show detail\&id=24902 Diakses pada tanggal 25 Maret 2019, Pukul 13.20 Wita.

Murasidi. 2019. Pengukuran Kualitas Pelayanan Pada Puskesmas Xyz Dengan Menggunakan Metode Servqual, Importance Performance Analysis Dan Potential Gain Customer Value. Volume 3 Nomor 1, Jurnal TIN

Tanjung Pura. http://jurnal.untan.ac.id/index.php/jtinUNT AN/article/view/32364 Diakses pada tanggal 25 Maret 2019, Pukul 12.47 Wita

Peraturan Menteri Kesehatan RI Nomor 75 Tahun 2014, tentang Pusat Kesehatan Masyarakat.

Peraturan Daerah (Perda) Provinsi Kaltara Nomor 2 Tahun 2017 tentang Pusat Kesehatan Masyarakat.

Sugiyono (2010). Metode Penelitian Kuantitatif, Kualitatif dan R\&D. Bandung: Alfabeta.

Zeithaml, Valarie A. and Bitner, Mary Jo. 2003. Service Marketing. McGraw Hill Inc, Int'l Edition, New York 